\title{
Pengaruh Pemberian Pupuk Kandang Ayam Terhadap Pertumbuhan dan Hasil Tanaman Sawi Pakcoy (Brassica Chinensis L.)
}

\author{
Inosensius Y. Wedhu ${ }^{1 *}$, Henderikus Darwin Beja ${ }^{2}$, Yuyun Wahyuni ${ }^{3}$ \\ ${ }^{1,2,3}$ Universitas Nusa Nipa, Nusa Tenggara Timur \\ *Email: inowedhu17@gmail.com, darwinbeja@ymail.com
}

\begin{abstract}
Sawi Pakcoy (Brassica chinensis L) is one of the horticultural plants of the Brassicaceae family which is still in the same genus as mustard greens and mustard greens, Sawi pakcoy is a plant that is quite popular and widely consumed by the public because it is very good for health and has high nutritional content. The purpose of this study was to determine the effect of giving chicken manure on the growth and yield of pakcoy (Brassica chinensis L.) plants. The method used in this study was a randomized block design (RBD) with four replications and six treatments, namely, P0: 0 tons / ha or without fertilizer, P1: 20 tons/ha, P2: 30 tons/ha, P3: 40 tons/ha, P4: 50 ton/ha, P5: 60 ton/ha. Based on the results of the analysis of variance using a randomized block design (RBD), it was found that the application of chicken manure had no significant effect on plant height, number of leaves, and had a very significant effect on fresh weight of Tan ${ }^{-1}$, and fresh weight of ha ${ }^{-1}$. The optimum dose of chicken manure 60 tons / ha is the best treatment for optimal growth and yield of pakcoy (Brassica chinensis L.) plants with an average production of fresh weight ha- ${ }^{-1}$ reaching 52.47 tons ha ${ }^{-1}$.
\end{abstract}

Keywords: Pakcoy Mustard; Chicken Manure Dose; Growth; Yield

\section{Pendahuluan}

Sawi Pakcoy (Brassica chinensis L.) merupakan salah satu tanaman hortikultura dari keluarga Brassicaceae yang masih berada dalam satu genus dengan sawi putih dan sawi hijau, Sawi pakcoy merupakan tanaman yang cukup populer dan banyak dikonsumsi masyarakat karena mengandung protein, lemak, Ca, P, Fe, Vitamin A, B, C, E dan $\mathrm{K}$ yang sangat baik untuk kesehatan dan mempunyai kandungan gizi tinggi (Eko, 2007).

Data Badan Pusat Statistik (BPS) dan Direktorat Jenderal Hortikultura (2015) yaitu produksi tanaman sawi pakcoy mengalami penurunan sekitar 5,23\% yaitu dari 635,728 ton/tahun pada 2013 menjadi hanya 602,468 ton/tahun pada tahun 2014. Penyebab terjadinya penurunan produksi tanaman sawi pakcoy adalah petani melakukan kegiatan budidaya tanaman pakcoy yang belum tepat terutama dalam hal pemupukan.

Pupuk anorganik atau pupuk buatan (dari senyawa organik) adalah pupuk yang sengaja dibuat oleh manusia dalam pabrik dan mengandung unsur hara tertentu dalam kadar tinggi. Dampak penggunaan pupuk kimia memiliki reaksi yang cepat bagi pertumbuhan tanaman akan tetapi dalam jangka panjang dapat mengeraskan tanah dan mengurangi kesuburan tanah (Dermiyati, 2015). Penggunaan pupuk kimia berkadar hara tinggi seperti Urea, ZA, TSP atau SP-36, dan KCL secara terus menerus dapat menyebabkan lingkungan tercemar jika tidak menggunakan aturan yang dianjurkan (Munir dan Arifin 2010).

Pupuk organik adalah pupuk yang bahan bakunya berasal dari tumbuhan dan hewan. Pupuk organik sangat mudah didapatkan di daerah sekitar kita dan ramah terhadap lingkungan sehingga tidak akan mengakibatkan kerusakan pada tanah.Pupuk organik merupakan pupuk yang bahan dasarnya berasal dari alam dengan jumlah dan jenis unsur hara yang terkandung secara alami. Fungsi dari pupuk organik adalah untuk memperbaiki kesuburan tanah, memperbaiki sifat fisik, kimia dan biologi tanah dan meningkatkan populasi mikroba tanah sehingga menekan aktivitas safrofitik dari pathogen tanaman serta tidak mencemari lingkungan (Yurnalis, 2006). Bahan organik merupakan penyangga persediaan unsur-unsur hara mikro dan makro bagi tanaman. Salah satu pupuk organik yang sering digunakan dalam budidaya tanaman adalah pupuk kandang ayam.

Pupuk kandang ayam merupakan pupuk kandang yang berasal dari kotoran ayam yang tercampur dengan sisa pakan ternak. Pupuk kandang ayam biasanya memiliki kandungan unsur hara yaitu $1 \% \mathrm{~N}, 0,8 \% \mathrm{P} 2 \mathrm{O}$, dan $0,4 \%$ K2O (Mayadewi, 2007). Sama seperti pupuk kadang lainnya pupuk kandang ayam memiliki nilai $\mathrm{C} / \mathrm{N}$ rasio yang masih tinggi yaitu di atas 28 , namun setelah terdekomposisi pupuk kandang ayam memiliki C/N ratio antara 10-20 (Surya dan Suyono, 2013). Pupuk kandang ayam memiliki kadar hara $\mathrm{N}$ dan $\mathrm{P}$ yang relatif lebih tinggi dari pupuk kandang lainnya. Kadar hara ini dipengaruhi oleh jenis pakan yang diberikan serta dalam kotoran ayam tersebut tercampur sisa-sisa makanan ayam yang dapat menyumbangkan tambahan hara. Selain itu, pupuk kandang ayam juga mengandung unsur mikro seperti seng ( $\mathrm{Zn})$, tembaga $(\mathrm{Cu})$, besi $(\mathrm{Fe})$, molybdenum (Mo) (Susantidkk., 2008). Hasil penelitian Cindra dkk (2005) menyatakan bahwa pemberian pupuk kandang ayam dengan dosis 20 ton/ha memberikan pengaruh terbaik terhadap pertumbuhan dan produksi tanaman sawi hijau dengan produksi sebesar $215 \mathrm{~g} / \mathrm{tanaman}$.

\section{Metodologi}

Penelitian dilaksanakan di Kebun Praktek Fakultas Pertanian Universitas Nusa Nipa Maumere, jalan Litbang, Kelurahan Kota Uneng, Kecamatan Alok, Kabupaten Sikka, Nusa Tenggara Timur. Kegiatan Penelitian dilaksana mulai 
dari bulan Oktober 2020 sampai dengan bulan Januari tahun 2021.

Penelitian ini di rancang menggunakan Rancangan Acak Kelompok (RAK) dengan enam (6) perlakuan dosis pupuk kandang ayam yaitu :

P0 : Tanpa pupuk (kontrol)

P1 : Pupuk kandang ayam 20 ton $\mathrm{ha}^{-1}$ atau $4 \mathrm{~kg} /$ petak

$\mathrm{P} 2$ : Pupuk kandang ayam 30 ton $\mathrm{ha}^{-1}$ atau $6 \mathrm{~kg} /$ petak

P3 : Pupuk kandang ayam 40 ton $\mathrm{ha}^{-1}$ atau $8 \mathrm{~kg} /$ petak

P4 : Pupuk kandang ayam 50 ton $\mathrm{ha}^{-1}$ atau $10 \mathrm{~kg} /$ petak

P5 : Pupuk kandang ayam 60 ton ha ${ }^{-1}$ atau $12 \mathrm{~kg} /$ petak

Persemaian dilakukan dalam bedengan dengan ukuran panjang $100 \mathrm{~cm} \times 100 \mathrm{~cm}$ dan tinggi bedengan 10 $\mathrm{cm}$. Tanah dibersihkan terlebih dahulu lalu digemburkan, media tanam terdiri atas campuran pupuk kandang ayam 1:1. Benih disebar secara merata diatas bedengan yang terlebih dahulu disiram air, dan naungan ditutup dengan paranet.

Pengolahan tanah meliputi pembersihan lahan, pembalikan tanah, pembuatan bedengan, dan pembuatan jarak tanam. Pembersihan lahan dan pembalikan tanah dilakukan bersamaan dan tujuan rumput atau gulma yang ada mengalami pembusukan terlebih dahulu. Pembuatan bedengan dilakukan setelah pembalikan tanah dengan ukuran panjang : $2 \mathrm{~m}$ dan lebar : $1 \mathrm{~m}$.

Pupuk kandang ayam di timbang terlebih dahulu, kemudian disebarkan pada setiap bedengan dengan dosis yang telah ditentukan yaituP0 :Tanpa pupuk atau 0ton ha${ }^{1}, \mathrm{P} 1: 20$ ton $\mathrm{ha}^{-1}$ atau $4 \mathrm{~kg} /$ petak, P2 : 30 ton $\mathrm{ha}^{-1}$ atau 6 $\mathrm{kg} /$ petak, $\mathrm{P} 3$ : 40 ton $\mathrm{ha}^{-1}$ atau $8 \mathrm{~kg} /$ petak, $\mathrm{P} 4: 50$ ton $\mathrm{ha}^{-1}$ atau $10 \mathrm{~kg} /$ petak, P5 : 60 ton ha ${ }^{-1}$ atau $12 \mathrm{~kg} /$ petak, lalu tanah diolah kembali agar pupuk kandang terbenam kedalam tanah. Pemberian pupuk kandang ayam dilakukan satu minggu sebelum melakukan penaanaman

Penanaman dilakukan dengan memindahkan anakan tanaman sawi pakcoy berumur 14 hari setelah persemaian dan sudah berbentuk 2-3 helai daun, kemudian dipinda ke bedengan yang sudah disiapkan dengan jarak tanam yang digunakan yaitu $25 \mathrm{~cm} \times 25 \mathrm{~cm}$.

Penyiraman dilakukan untuk mencukupi ketersediaan air bagi tanaman sawi pakcoy. Penyiraman dilakukan 2 kali sehari yaitu pada pagi dan sore hari, sesuai dengan kondisi tanaman dan media tanaman sawi pakcoy.

Penyulaman dilakukan apabila tanaman yang mati, digantikan dengan tanaman baru dari tempat persemaian. Penyiangan merupakan kegiatan pembersihan gulma. Tujuan penyiangan: adalah membersihkan rumput-rumput dan tanaman lain yang tidak dikehendaki agar tidak menjadi pesaing dalam penyerapan unsur hara dalam tanah. Pemanenan dilakukan dengan cara mencabut semua tanaman berserta akarnya. Umur panen sawi pakcoy25hari setelah tanam.

\section{Hasil}

Berdasarkan hasil analisis statistik menunjukkan bahwa pemberian pupuk kandang ayam terhadap pertumbuhan dan hasil tanaman sawi pakcoy (Brassica chinensis L.) tidak memberikan pengaruh nyata terhadap tinggi tanaman, jumlah daun, namun berpengaruh sangat nyata terhadap berat segar $\tan ^{-1}$ dan berat segarha ${ }^{1}$.

Tabel 1. Signifikasi pengaruh pupuk kandang ayam terhadap pertumbuhan dan hasil tanaman sawi pakcoy

\begin{tabular}{llc}
\hline \multirow{2}{*}{ NO } & \multicolumn{1}{c}{ Variabel } & Signifikasi \\
\cline { 3 - 3 } $\mathbf{1}$ & Tinggi tanaman umur 14 hst & Perlakuan \\
\hline $\mathbf{2}$ & Tinggi tanaman umur 21 hst & TN \\
\hline $\mathbf{3}$ & Jumlah daun umur 14 hst & TN \\
\hline $\mathbf{4}$ & Jumlah daun umur 21 hst & TN \\
\hline $\mathbf{5}$ & Berat segar tan $^{-1}$ & TN \\
\hline $\mathbf{6}$ & Berat segar ha $^{-1}$ & $* *$ \\
\hline
\end{tabular}

Keterangan :

TN :Tidak Nyata

** :Sangat Nyata

Hasil analisis sidik ragam menunjukkan bahwa pemberian pupuk kandang ayam terhadap pertumbuhan danhasil tanaman sawi pakcoy (Brassica rapa L.) tidak memberikan pengaruh nyata terhadap tinggi tanaman dan jumlah daun tanaman sawi pakcoy (Brassica chinensisL.). 
Tabel 2. Pengaruh Pupuk Kandang Ayam Terhadap Tinggi Tanaman (cm) dan Jumlah Daun Tanaman Sawi Pakcoy (Brassica chinensisL.)

\begin{tabular}{|c|c|c|c|}
\hline \multirow{2}{*}{ Variabel } & \multirow{2}{*}{ Perlakuan } & \multicolumn{2}{|c|}{ Umur pengamatan (hst) } \\
\hline & & 14 & 21 \\
\hline \multirow{6}{*}{$\begin{array}{l}\text { Tinggi tanaman } \\
(\text { (cm) }\end{array}$} & P0 & $3,67 \mathrm{a}$ & $18,50 \mathrm{a}$ \\
\hline & P1 & $5.00 \mathrm{a}$ & $19,71 \mathrm{a}$ \\
\hline & $\mathbf{P 2}$ & $5,76 \mathrm{a}$ & $20,08 \mathrm{a}$ \\
\hline & P3 & $6,83 \mathrm{a}$ & $22,46 \mathrm{a}$ \\
\hline & P4 & $6,96 \mathrm{a}$ & $23,33 \mathrm{a}$ \\
\hline & P5 & $7,63 \mathrm{a}$ & $24,21 \mathrm{a}$ \\
\hline \multirow{6}{*}{$\begin{array}{c}\text { Jumla Daun } \\
\text { (helai) }\end{array}$} & P0 & $4,13 \mathrm{a}$ & $7,83 \mathrm{a}$ \\
\hline & P1 & $4,98 \mathrm{a}$ & $7,21 \mathrm{a}$ \\
\hline & $\mathbf{P 2}$ & $4,92 \mathrm{a}$ & $7,42 \mathrm{a}$ \\
\hline & P3 & $5,21 \mathrm{a}$ & $8,46 \mathrm{a}$ \\
\hline & P4 & $5,29 \mathrm{a}$ & $8,92 \mathrm{a}$ \\
\hline & P5 & $5,67 \mathrm{a}$ & $9,33 \mathrm{a}$ \\
\hline
\end{tabular}

Keterangan : Angka-angka yang diikuti oleh huruf yang sama pada kolom yang sama menunjukkan tidak berbeda nyata pada taraf uji BNT 5\%

Hasil analisis sidik ragam menunjukkan bahwa pemberian pupuk kandang ayam terhadap tinggi tanaman sawi pakcoy menunjukkan tidak berpengaruh nyata. Pernyataan ini menunjukkan bahwa hipotesis 1 ditolak karena tidak nyata memberikan pengaruh pertumbuhan dan tinggi tanaman sawi pakcoy, yang artinya bahwa secara keseluruhan memberikan hasil rata-rata yang sama, hal ini dipengaruhi oleh ketersediaan pupuk organik yang belum matang sehingga unsur hara yang terdapat pada media tanam belum diserap secara optimal oleh tanaman, karena rentang waktu aplikasi dengan masa penanaman bibit terlalu singkat, dan respon tanaman terhadap pupuk organik lebih lambat karena pupuk orgabersifat lambat pelepasan nik unsure haranya.

Menurut Liu dkk., (2014) yang menyatakan bahwa kandungan nitrogen yang berada di dalam pupuk organik bersifat lambat pelepasan sehingga sulit diserap oleh akar sebagai elemen penting untuk pertumbuhan tanaman yang optimal. Tanaman mengalami kekurangan unsur $\mathrm{N}$ dapat menghambat pertumbuhan tanaman karena $\mathrm{N}$ berfungsi untuk meningkatkan pertumbuhan tinggi tanaman (Surya dan suyono 2013).

Hasil analisis sidik ragam menunjukkan bahwa pemberianpupuk kandang ayam terhadap jumlah daun tanaman sawi pokcay menunjukkan tidak pengaruh nyata, pernyataan ini menunjukkan bahwa hipotesis 1 ditolak kerena tidak memberikan pengaruh pertumbuhan jumlah daun,artinya bahwa secara keseluruhan memberikan hasil rata-rata yang sama.hal inidipengaruhi oleh unsur $\mathrm{N}$ berperan sebagai pembentuk klorofil untuk proses fotosintesis bagi tanaman,jika tanaman kekurangan unsur $\mathrm{N}$ maka jumblah klorofil akan semakin sedikit dan proses fotosintesis akan semakin sedikit sehingga laju penyerapan unsur hara akan semakin sedikit yang disalurkan pada semua bagian tanaman, sehingga berdampak pada pertumbuhan tinggi tanaman dan jumlah daun tanaman sawi pakcoy.

Menurut Wawan dan Nasrul (2012), Semakin tersedianya unsur hara maka semakin baik proses pertumbuhan dan perkembangan suatu tanaman. Suseno (2017) Menyatakan bahwa tanaman yang kekurangan unsure hara akan terganggu proses metabolismenya sehingga pertumbuhan semakin menjadi terlambat. Menurut Agus dan Wulandari (2012) menyebutkan bahwa keberadan bahan organik, vegetasi pionir dan endomikorisa adaptif dapat menstimulasi pemulihan kualitas lahan paska erupsi Merapi dengan perbaikan sifat fisika, kimia dan biologi tanah, yang selanjutnya meningkatkan pertumbuhan dan biodiversitas tanaman. Menurut (Kusuma, 2012) Pemberian pupuk kandang lebih efektif dalam meningkatkan pertumbuhan tanaman karena pupuk kandang memiliki kandungan hara yang lengkap dalam memenuhi kebutuhan tanaman. Pupuk kandang yang berasal dari kotoran hewan mengandung unsur hara makro seperti nitrogen $(\mathrm{N})$, posfor $(\mathrm{P})$, kalium $(\mathrm{K})$, kalsium $(\mathrm{Ca})$, magnesium $(\mathrm{Mg})$ dan belerang $(\mathrm{S})$, sehingga dapat memenuhi kebutuhan unsur hara tanaman sawi pakcoy. Pemberian pupuk kandang ayam menghasilkan jumlah daun terbanyak, hal ini dikarenakan pupuk kandang ayam mengandung nitogen yang tinggi dalam memenuhi kebutuhan nutrisi tanaman, serta memiliki unsure $\mathrm{N}$ yang rendah sehingga nitrogen mudah diserap oleh tanaman. Pertumbuhan tanaman memerlukan suplai nitrogen yang cukup dan berimbang dengan unsur hara lainnya, selain itu unsur hara yang tersedia juga harus sesuai agar dapat diserap oleh tanaman (Ningsih 2013).

Menurut Wijaya (2008) tanaman yang cukup mendapatkan suplai $\mathrm{N}$ akan membentuk helai daun yang dengan kandungan klorofil yang tinggi sehingga tanah dapat 
menghasilkan asimilat dalam jumlah cukup untuk menopang pertumbuhan vegetatifnya. Hal ini dipengaruhi faktor lingkungan diantaranya intensitas cahaya matahari. Menurut Rukmana (2002) menyatakan bahwa sinar matahari berperan cukup besar bagi kehidupan tanaman sawi pakcoy, terutama dalam proses fotosintesis. Tanaman sawi pakcoy menghendaki areal pertanaman terbuka karena tanaman ini memerlukan penyinaran yang cukup selama pertumbuhan bibit sampai tanaman berproduksi, minimal sekitar 70\% intensitas cahaya matahari.

Hasil analisis sidik ragam menunjukkan bahwa dosis pupuk kandang ayamyang diberikanberpengaruh sangat nyata terhadap berat (gr) segar $\tan ^{-1}$ dan berat (ton) segar ha${ }^{1}$ Tanaman sawi pakcoy (Brassica chinensisL.).

Tabel 3. Pengaruh Pupuk kandang Ayam Terhadap HasilTanaman

\begin{tabular}{ccc}
\hline \multirow{2}{*}{ Perlakuan } & \multicolumn{2}{c}{ Rata-rata Variabel Hasil } \\
\cline { 2 - 3 } & $\begin{array}{c}\text { Berat segar sawi pakcoy } \\
\text { tan }^{-1}\end{array}$ & Berat segar sawi pakcoy ha-1 $^{-1}$ \\
\hline P0 & $55,17 \mathrm{a}$ & $8,83 \mathrm{a}$ \\
\hline P1 & $102,50 \mathrm{~b}$ & $16,38 \mathrm{~b}$ \\
\hline P2 & $105,63 \mathrm{c}$ & $16,90 \mathrm{c}$ \\
\hline P3 & $158,71 \mathrm{~d}$ & $25,39 \mathrm{~d}$ \\
\hline P4 & $217,50 \mathrm{e}$ & $34,77 \mathrm{e}$ \\
\hline P5 & $327,92 \mathrm{f}$ & $52,47 \mathrm{f}$ \\
\hline
\end{tabular}

Keterangan : Angka-angka yang diikuti oleh huruf yang sama pada kolom yang sama menunjukan tidak berbeda nyata pada taraf uji BNT 5\%

BS $\tan ^{-1}$ : Berat Segar per tanaman

$\mathrm{BS} \mathrm{ha}^{-1}$ : Berat Segar per hektar

Hasil analisis sidik ragam menunjukkan bahwa pemberian pupuk kandang ayam terhadap berat segar tan ${ }^{1}$ dan berat segat ha $^{-1}$ menunjukkan pengaruh yang sangat nyata.Hasil tertinggi diperoleh pada perlakuan pemberian pupuk kandang ayam 60 ton/ha (P5) dengan hasil rata-rata 52,47 ton $^{-1}$ dan hasil terendah diperoleh pada perlakuan pemberian pupuk kandang ayam (P0) tanpa pupuk 0ton ha ${ }^{-1}$ dengan hasil rata-rata 8,83 ton $\mathrm{ha}^{-1}$, atau terjadi peningkatan hasil sebesar $83,17 \%$, jika dibandingkan antara kedua perlakuan tersebut atau memiliki selisi sebesar 43,64 ton ha 1. Pernyataan ini menunjukan bahwa hipotesis 2 diterimakarena dosis pupuk kandang ayam 60ton ha${ }^{1}$ menunjukkan hasil yang terbaik karena berdasarkan hasil uji beda rata-rata menggunakan uji beda nyata terkecil (BNT) 5\%.Hal ini kemungkinan unsur hara dalam pupuk kandang ayam sudah tersedia bagi tanaman Pada fase generatif, tanaman sawi pakcoy sangat di butukan unsur hara N,P dan $\mathrm{K}$ dalam proses pertumbuhan karena unsur N,P dan $\mathrm{K}$ berperan penting dalam pertumbuhan tanaman sawi pakcoy, perlu kita ketahui krakteristik dari pupuk kandang ayam membutukan waktu yang relatif lebih lama untuk dapat diurai dan diubah menjadi keadaan tersedia sehingga dapat diserap dan dimanfatkan oleh tanaman. Kenyataan ketersediaan unsur hara semulanya dapat dipasok dari pemupukan ini justru tida dimanfaatkan secara optimal, sebab pada saat tanaman sedang membutukan unsure hara untuk pertumbuhan pada fase vegetatif, justru pupuk kandang ayam yang diberikan pada tanaman masih berada dalam kondisi belum tersedia.Sehingga aplikasi pupuk kandang ayam secara umum sesuai dengan data pengamatan dilapangangn tidak memberikan hasil yang cukup berarti,pupuk organik adalah pupuk yang biasanya pupuk yang diberikan kepada tanaman dengan tujuan untuk memperbaiki sifat fisik tanah,baik dari tekstur maupun strukturnya, sehingga dapat mempermudakan proses perkembangan perakaran tanaman, yang pada gilirannya dapat mempengaruhi positif terhadap laju pertumbuhan tanaman. Hal itu pupuk organik juga dilengkapi dengan hara mikro untuk pertumbuhan tanaman sehingga pemupukan bahan organik dapat memberikan efek terhadap pertumbuhan dan hasil tanaman yang cukup baik, jika diberikan dengan cara dan waktu yang tepat.

Menurut Sarief (1989), menyatakan bahwa dengan tersedianya unsur hara dalam jumlah memadai, maka proses fisiologis di dalam tanaman akan berjalan baik, terutama unsur hara yang berperan dominan dalam pertumbuhan dan perkembangan tanaman. Hasil fotosintesis yang berupa karbohidrat selain disuplai ke batang, daun dan akar juga disuplai untuk perkembangan generatif tanaman, dan tersimpan sebagai cadangan makanan (Harjadi, 1989). Pemberian pupuk kandang dapat meningkatkan bahan organik dalam tanah sehingga pertumbuhan dan produksi tanaman lebih optimal (Azizah dkk., 2016). Pupuk kandang ayam menghasilkan produksi tertinggi dibandingkan dengan perlakuan lain, hal ini dikarenakan pupuk kandang ayam memiliki unsure $\mathrm{N}$ yang tinggi dibandingkan pupuk kandang lain sehingga unsur $\mathrm{N}$ lebih mudah diserap tanaman. Pupuk kandang ayam mengandung unsur hara yang lengkap bagi pertumbuhan tanaman, meningkatkan kesuburan tanah, serta meningkatkan daya tahan dan daya serap tanah terhadap air sehingga akar dapat lebih mudah menyerap unsur hara (Pinem dkk., 2015). 
Menurut Lingga dan Marsono (2007) menyatakan bahwa respon pupuk yang diberikan sangat ditentukan berbagai faktor antara lain sifat genetik dari tanaman, iklim, tanah, dimana faktor-faktor tersebut tidak berdiri sendiri tetapi saling berkaitan dengan faktor-faktor yang lain.

Pertumbuhan bagian vegetatif tanaman membutuhkan unsur N P dan K dalam jumlah relatif besar (Novizan, 2005). Unsur $\mathrm{N}$ merupakan unsur hara utama bagi pertumbuhan tanaman yang pada umumnya sangat diperlukan untuk pertumbuhan vegetatif tanaman (Sutedjo, 2002). Unsur $P$ dan $K$ juga mempunyai peranan yang penting untuk proses pertumbuhan, dan membantu pembentukan protein dan karbohidrat, berperan memperkuat tubuh tanaman (Anonimus, 2010). Menurut Anonimus (2007), menjelaskan bahwa peranan langsung bahan organik adalah untuk menyuplai nutrien bagi tanaman. Bahan organik yang ditambahkan ke dalam tanah akan menambah unsur hara baik makro maupun mikro yang dibutuhkan oleh tumbuhan. Efisiensi nutrisi tanaman meningkat apabila permukaan tanah dilindungi dengan bahan organik (Sarwono 2007).

\section{Kesimpulan}

Pemberian pupuk kandang ayamberpengaruh tidak nyataterhadap tinggi tanaman, jumlah daun, namun berpengaruh sangat nyata terhadap berat segar $\tan ^{-1}$, serta berat segar ha ${ }^{-1}$.

Dosis optimum pupuk kandang ayam 60 ton $\mathrm{ha}^{-1}$ merupakan perlakuan terbaik untuk pertumbuhan dan hasil tanaman sawi pakcoy (Brassica chinensisL.) yang optimal dengan produksi rata-rata berat segar $\mathrm{ha}^{-1}$ mencapai 52,47 ton $\mathrm{ha}^{-1}$.

\section{Daftar Pustaka}

Azizah, N., G. Haryono dan Tujiyanta. 2016. Respon macam pupuk organik dan macam mulsa terhadap hasil tanaman sawi caisin (Brassica juncea L.) var. tosakan. Vigor Jurnal Ilmu Pertanian Tropika danSubtropika. 1 (1): 44-51.

Agus, C., dan Wulandari, D. 2012. The Abundance of Pioneer Vegetation and Their Interaction with Endomycorrhizae at Different Land Qualities after Merapi Eruption. JMHT 18(3): 145-154.

Cahyono, B. 2003. Teknik dan Strategi Budidaya Sawi Hijau (Pai-Tsai). Hal 12- 62. Yogyakarta : Yayasan Pustaka Nusatama.
Cindra, D. S., Pomalingo, \& Nurmi. 2013. Pertumbuhan dan Produksi Tanaman Sawi dengan Pemberian Dosis Pupuk Organik Kotoran Ayam. Universitas Gorontalo. Gorontalo.

Direktorat Jenderal Hortikultura. 2015. Statistik Produksi Hortikultura 2014. Diakses pada tanggal 6 Maret 2018.

Eko. 2007. Budidaya Tanaman Sayur Sawi Pakcoy. Jakarta: Penerbit Swadaya.

Endang. 2007. Pengaruh Takaran Pupuk Organik dan Pupuk Nitrogen terhadapPertumbuhan Vegetatif Mentimun (Cucumis sativus L.). Fakultas Pertanian. Institut Pertanian Bogor.

Haryanto, E., Suhartini, T., \& Rahayu, E. (2007). Sawi dan selada. Jakarta: PenebarSwadaya

Inonu1, N.S., L. Khodijah, dan A. Supriadi. 2014. Keragaan lahan suboptimal dan perbaikan produktivitas melalui kebijakan daerah di Lampung. Prosiding Seminar Nasional Lahan Suboptimal 2014, Palembang 26-27 September 2014 ISBN : 979-587-529-9.

Kusuma, M. E. 2012. Pengaruh beberapa jenis pupuk kandang terhadap kualitas bokashi. J. Ilmu. Hewani. Tropika. 1 (2) : 41-46.

Liu, C. W., Y. Sung, B. C. Chen, \& H. Y. Lai. (2014). Effects of nitrogen fertilizers on the growth and nitrate content of lettuce (Lactuce sative L.). International Journal of Environmental Research and Public Health

Ningsih, S.S. 2013. Pengaruh pemberian pupukkandang ayam dan pupuk $N$ (ZA) terhadappertumbuhan serta produksi tanaman sawi(Brassica juncea L.). J. Penelitian PertanianBERNAS. 9 (1): 1-6.

Mayadewi, A. 2007. Pengaruh Jenis Pupuk Kandang dan Jarak Tanam terhadap Pertumbuhan Gulma Hasil Jagung Manis. Agritrop, 26 (4) : 153-159 ISN : 02158620.

Pracaya \& Kartika, J. K. 2016. Bertanam 8 Sayuran Organik. Jakarta (ID): Penebar Swadaya

Pinem, D.Y.F., T, Irmansyah dan F.E.T. Sitepu.2015. Respon pertumbuhan dan produksi

Setyamidjaja, D. 1986. Pupuk dan Pemupukan. CV Simplex. Jakarta.

Setyaningrum, H. D dan C. Saparinto. 2011. Panen Sayur Secara Rutin di Lahan Sempit. Penebar Swadaya, Jakarta.

Sumarni, N. dan A. Hidayat.2005. Panduan Teknis Budidaya Sawi Pakcoy. Balai Penelitian Tanaman Sayuran. Pusat Penelitian dan Pengembangan Pertanian. Badan Penelitian dan Pengembangan Pertanian. 20Hlm.

Sunarjono H. 2013. Budidaya dan Pengaturan Panen Sayuran Dataran Rendah Jakarta : Penebar Swadaya.

Surya, R.E., Suryono. 2013. Pengaruh pengomposan terhadap rasio $\mathrm{C} / \mathrm{N}$ kotoran ayam dan kadar hara NPK tersedia serta kapasitas tukar kation tanah. UNESA Journal of Chemistry 2(1): 137-144.

Sutanto. 2002. Penerapan Pertanian Organik. Kanisius. Jakarta.

Widowati, L.R., Sri Widati, U. Jaenudin, dan W. Hartatik. 2005. Pengaruh Kompos Pupuk Organik yang Diperkaya dengan Bahan Mineral dan Pupuk Hayati terhadap Sifat-sifat Tanah, Serapan Hara dan Produksi Sayuran Organik. Laporan Proyek Penelitian Program Pengembangan Agribisnis, Balai Penelitian Tanah. 